\title{
Influence of Simulated Microgravity on Leg Bone Development in Japanese Quail Chicks
}

\author{
P. ŠKROBÁNEK, M. BARANOVSKÁ, M. JURÁNI, B. ŠÁRNIKOVÁ \\ Institute of Animal Biochemistry and Genetics, Slovak Academy of Sciences, Ivanka pri Dunaji, \\ Slovak Republic \\ Received December 10, 2004 \\ Accepted November 10, 2005
}

\begin{abstract}
Škrobánek, P., M. Baranovská, M. Juráni, B. Šárniková: Influence of Simulated Microgravity on Leg Bone Development in Japanese Quail Chicks. Acta Vet. Brno 2005, 74: 475-481.

The goal of this study was to assess the influence of simulated microgravity (hypodynamy) on morphological characteristics and mineral content of the long bones of the right leg of female Japanese quail chicks from 3 to 56 days of age. Femur and tibiotarsus were collected at 14, 28, 42 and 56 days; the variables studied were: weight $(\mathrm{g})$, length and width $(\mathrm{mm})$, bone index (ash weight/bone length in $\mathrm{mg} \cdot \mathrm{mm}^{-1}$ ), bone breaking strength $(\mathrm{N})$ and calcium, phosphorus and magnesium content ( $\mathrm{mg} \cdot \mathrm{g}^{-1}$ dry bone).

All variables increased with bird age. However, the effect of hypodynamy on the examined variables was frequently large and significant. The tibiotarsus mean weight was significantly $(P<$ 0.001 ) reduced by $0.154 \mathrm{~g}$, although the femur mean weight in hypodynamy reared quails was almost identical to that of the age-matched control at 56 days. Similarly, there was significantly decreased tibiotarsus mean length $(P<0.01)$ by $3.16 \mathrm{~mm}$ and tibiotarsus mean width $(P<0.001)$ by $0.44 \mathrm{~mm}$ by 56 days. Similarly, bone index and bone breaking strength of both bones in birds reared under hypodynamy were significantly lower $(P<0.001)$ than those of control. Moreover, hypodynamy significantly $(P<0.01)$ decreased the calcium content in femur and tibiotarsus at 42 days; phosphorus content in tibiotarsus was reduced significantly at 14 and 42 days $(P<0.001 ; P<$ 0.05 , respectively) and magnesium content was decreased at 42 days $(P<0.01)$. On the contrary, magnesium content in both long bones of test quails was increased significantly $(P<0.01)$ at 14 days. Other differences in femur and tibiotarsus mineral content between test and control group were not significant. These findings suggest that, although hypodynamy reduce bone growth of test birds, the long bones of the right leg of female Japanese quail were able to develop under conditions of simulated microgravity.
\end{abstract}

Hypodynamy, femur, tibiotarsus, calcium, phosphorus, magnesium

In humans and other mammals, the microgravity has been observed to have a negative impact on bone homeostasis as a result of reduced calcium absorption and negative calcium balance during extended space flight duration (D a niel et al. 1997). Similarly, the simulated microgravity caused reduction in mineral content of leg bones of adult Japanese quail as compared to control birds (Sviatk o et al. 1998). However, it is unknown, how simulated microgravity or long-duration space flight may influence the avian and human postnatal development during the subsequent ontogenetic phases. A partial answer may be provided by the ground-based animal and human models of simulated microgravity (hypodynamy).

During the last three decades, the effects of microgravity on embryogenesis of Japanese quail have been studied. The results show that in some instances quail embryogenesis can be performed in the environment of weightlessness without serious difficulties (Guryeva et al. 1993; Dadasheva et al. 2001). Quail chicks developing to hatch had all external characteristics of a normal development. In flight experiments on board MIR space station, there were successfully hatched 8 (March 1990) and 36 (February 1999) quail chicks from 21 and 56 fertilised eggs (Bod'a et al. 1992; Sabo et al. 2001).

\footnotetext{
Address for correspondence:

Ing. Peter Škrobánek, CSc.

Institute of Animal Biochemistry and Genetics

Slovak Academy of Sciences

Moyzesova 61, 90028 Ivanka pri Dunaji

Slovak Republic
}

Phone: + 4210245943881

Fax: + 4210245943932

E-mail: ubgzskro@savba.sk

http://www.vfu.cz/acta-vet/actavet.htm 
The first studies to examine the effect of hypodynamy were conducted with adult Japanese quail (Juráni et al. 1983). However, there are minimal data on survival and development of Japanese quail chicks in conditions of hypodynamy (Šk krobánek et al. 2001; Škrobánek and Hrančová 2003).

The purpose of the present study was to investigate the influence of simulated microgravity (hypodynamy) on long bone (femur and tibiotarsus) development in female Japanese quail chicks reared under hypodynamy from day 3 posthatch to 56 days.

\section{Materials and Methods}

Eighty female, newly-hatched Japanese quail chicks (Laying Line 01 Ivanka pri Dunaji), mean body weight 7.29 $\pm 0.43 \mathrm{~g}$, were used in the present study. On the third day after hatching, forty-one chicks (test group) were exposed to hypodynamy (as described in Škrobánek et al. 2001). Hypodynamy is a simulation of weightlessness where quails are placed in individual slings suspended by a flexible metal device such that their legs cannot touch the floor. However, chicks may move about freely by moving their wings. The size of the slings was enlarged at $7,14,21$, 28 and 35 day to age (from $4 \mathrm{~cm} \times 3 \mathrm{~cm}$ to $5 \mathrm{~cm} \times 4 \mathrm{~cm}$ to $6 \mathrm{~cm} \times 5 \mathrm{~cm}$ to $7 \mathrm{~cm} \times 6 \mathrm{~cm}$ and $8 \mathrm{~cm} \times 7 \mathrm{~cm}$ ) to accommodate the growth of the quail. At the same time, thirty-nine quail chicks (control group) were placed in a rearing box $(1.2 \times 0.6 \times 0.3 \mathrm{~m})$. The birds of both test and control groups were kept in these conditions until 56 days of age in a windowless poultry room with controlled ventilation and heating by infrared lamps. The temperature was gradually reduced from $35-36^{\circ} \mathrm{C}$ for the first few days after hatching to about $20^{\circ} \mathrm{C}$ at 4 weeks, remaining at this level until the end of the experiment. A commercial starter mash HYD-13 and water were available ad libitum. The granular diet contained $260 \mathrm{~g} / \mathrm{kg}$ protein and $11.5 \mathrm{MJ}$ metabolisable energy $/ \mathrm{kg}$. Lighting in the rearing room was continuous. The care and use of animals were in accordance with laws and regulations of the Slovak Republic and as approved by the ethical committee of the Institute of Animal Biochemistry and Genetics of Ivanka pri Dunaji.

Test and control quail were killed by cervical dislocation at 14, 28, 42 and 56 days. Thirty-two (test) and thirty-five (control) right femur and tibiotarsus samples were removed from the quail, dissected free of muscle, ligaments and tendons. The weight of freshly dissected bones was recorded (g). The length and width of the bones were measured using hand callipers $(\mathrm{mm})$. Breaking strength $(\mathrm{N})$ of the femur and tibiotarsus was measured on a materials testing apparatus (developed by Marcinka and Gažo 1964). The bone index (proposed by Seedor et al. 1991), that represents an index of bone density, was calculated by dividing bone ash weight by bone length $\left(\mathrm{mg} \cdot \mathrm{mm}^{-1}\right)$. Bones were defatted by submerging in diethyl ether for 2 hours and placed in an oven at $105^{\circ} \mathrm{C}$ for 4 hours and the dry weight measured. Bones were ashed in a furnace at 550 ${ }^{\circ} \mathrm{C}$ for 6 hours and ash weight obtained. The ash was dissolved in $2.5 \mathrm{ml}$ hydrochloric acid (water solution 1:1) and diluted to $50 \mathrm{ml}$ using redistilled water. The content of calcium, inorganic phosphorus and magnesium was determined by colourimetric kit assay (BIO-LA-TEST, Lachema Brno, Czech Republic). The results were expressed as milligrams of calcium, phosphorus and magnesium per gram of dry bone weight (femur, tibiotarsus). Statistical comparisons between the overall mean values for test and control groups were calculated using the Student's t-test.

\section{Results}

The effects of hypodynamy on bone weight, length and width are summarised in Table 1 . We observed that the femur and tibiotarsus absolute weight gradually increased with age in both groups. However, the bone weight of hypodynamy quail was significantly smaller than that of age-matched controls already by day $14(P<0.001)$. The maximum differences in femur and tibiotarsus weight were observed on day 28. By 56 days, the quail reared in the hypodynamy were unable to make up this difference, regardless of the increased bone weight gains. Femur and tibiotarsus of the test group showed reduced weight by 0.05 and $0.154 \mathrm{~g}(P<0.001)$ vs. control.

Similarly, tibiotarsus absolute length was affected by hypodynamy $(P<0.001)$, but no significant differences in femur length were found between the experimental and control groups. At day 56, the mean tibiotarsus length of hypodynamy quail was decreased by nearly $3 \mathrm{~mm}(P<0.01)$.

The mean long bone width was altered throughout the experimental period. At 56 days, animals exposed to hypodynamy had significantly $(P<0.001)$ decreased absolute tibiotarsus width (by $0.44 \mathrm{~mm}$ ) and slightly lower femur width (by $0.01 \mathrm{~mm}$ ) when compared to controls. 
Table 1. Weight, length and width of Japanese quail long bones

\begin{tabular}{|c|c|c|c|c|}
\hline $\begin{array}{c}\text { Age } \\
\text { (days })\end{array}$ & Femur & \multicolumn{2}{c|}{ Tibiotarsus } \\
\hline & $\mathrm{H}$ & $\mathrm{C}$ & $\mathrm{H}$ & $\mathrm{C}$ \\
\hline \multicolumn{5}{|c|}{ Weight $(\mathrm{g})$} \\
\hline 14 & $0.162 \pm 0.015^{+++}$ & $0.215 \pm 0.023$ & $0.204 \pm 0.026^{+++}$ & $0.285 \pm 0.021$ \\
\hline 28 & $0.256 \pm 0.052^{+++}$ & $0.436 \pm 0.025$ & $0.331 \pm 0.078^{+++}$ & $0.528 \pm 0.057$ \\
\hline 42 & $0.355 \pm 0.018^{+++}$ & $0.458 \pm 0.036$ & $0.394 \pm 0.044^{+++}$ & $0.537 \pm 0.055$ \\
\hline 56 & $0.461 \pm 0.061$ & $0.511 \pm 0.051$ & $0.445 \pm 0.048^{+++}$ & $0.599 \pm 0.053$ \\
\hline \multicolumn{5}{|c|}{ Length (mm) } \\
\hline 14 & $24.69 \pm 1.54$ & $25.99 \pm 1.21$ & $29.60 \pm 1.80^{+}$ & $32.45 \pm 1.01$ \\
\hline 28 & $32.50 \pm 3.41$ & $35.10 \pm 0.99$ & $38.50 \pm 3.52^{+++}$ & $43.20 \pm 1.07$ \\
\hline 42 & $36.47 \pm 1.02$ & $36.30 \pm 0.70$ & $44.06 \pm 1.20^{+++}$ & $46.90 \pm 0.94$ \\
\hline 56 & $36.67 \pm 0.27$ & $37.35 \pm 0.75$ & $44.30 \pm 1.60^{++}$ & $47.46 \pm 1.10$ \\
\hline \multicolumn{5}{|c|}{ Width (mm) } \\
\hline 14 & $1.60 \pm 0.25^{++}$ & $1.90 \pm 0.20$ & $1.50 \pm 0.13^{+++}$ & $1.70 \pm 0.17$ \\
\hline 28 & $2.10 \pm 0.21^{+++}$ & $2.35 \pm 0.08$ & $1.80 \pm 0.12^{+++}$ & $2.15 \pm 0.10$ \\
\hline 42 & $2.30 \pm 0.18^{+++}$ & $2.60 \pm 0.08$ & $2.05 \pm 0.15^{+++}$ & $2.45 \pm 0.07$ \\
\hline 56 & $2.61 \pm 0.17$ & $2.62 \pm 0.21$ & $2.00 \pm 0.18^{+++}$ & $2.44 \pm 0.09$ \\
\hline
\end{tabular}

${ }^{+} \mathrm{P}<0.05 ;{ }^{++} \mathrm{P}<0.01 ;{ }^{+++} \mathrm{P}<0.001$

$\mathrm{H}$ - hypodynamy, $\mathrm{C}$ - control

Table 2. Effect of hypodynamy on bone index (ash weight / bone length) and breaking strength of Japanese quails

\begin{tabular}{|c|c|c|c|c|}
\hline $\begin{array}{c}\text { Age } \\
\text { (days) }\end{array}$ & \multicolumn{3}{|c|}{ Femur } & \multicolumn{2}{c|}{ Tibiotarsus } \\
\hline & $\mathrm{H}$ & $\mathrm{C}$ & $\mathrm{H}$ & $\mathrm{C}$ \\
\hline \multicolumn{5}{|c|}{ Bone index $(\mathrm{mg} / \mathrm{mm})$} \\
\hline 14 & $0.976 \pm 0.092^{++}$ & $1.117 \pm 0.072$ & $1.001 \pm 0.114$ & $1.170 \pm 0.160$ \\
\hline 28 & $1.462 \pm 0.301$ & $1.592 \pm 0.186$ & $1.031 \pm 0.078^{++}$ & $1.144 \pm 0.073$ \\
\hline 42 & $1.258 \pm 0.058^{+}$ & $1.366 \pm 0.090$ & $1.056 \pm 0.055^{++}$ & $1.158 \pm 0.056$ \\
\hline 56 & $1.311 \pm 0.199$ & $1.427 \pm 0.251$ & $1.081 \pm 0.102$ & $1.192 \pm 0.224$ \\
\hline \multicolumn{5}{|c|}{ Breaking strength $(\mathrm{N})$} \\
\hline 14 & $25.166 \pm 1.000^{+++}$ & $29.160 \pm 1.054$ & $20.313 \pm 1.100^{+++}$ & $24.111 \pm 0.740$ \\
\hline 42 & $31.333 \pm 1.960^{+++}$ & $46.214 \pm 1.046$ & $24.063 \pm 1.321^{+++}$ & $37.875 \pm 3.640$ \\
\hline
\end{tabular}

${ }^{+} \mathrm{P}<0.01 ;{ }^{++} \mathrm{P}<0.001$

$\mathrm{H}$ - hypodynamy, $\mathrm{C}$ - control

The effect of hypodynamy on bone index and bone breaking strength are shown in Table 2.

The bone index (ash weight/bone length) in the experimental group was lower than in the control group. The femur index for quail reared in hypodynamy decreased significantly at 14 and 42 days $(P<0.05)$ and the tibiotarsus index at 28 and 42 days $(P<0.01)$.

The bone breaking strength increased markedly between 14 and 42 days in both groups, although hypodynamy significantly reduced the femur and tibiotarsus breaking strength $(P<0.001)$.

The results of the measurements of calcium in the long bones of quail chicks exposed to hypodynamy vs. controls are presented on Fig.1 and 2. Femur and tibiotarsus calcium contents were similar throughout the entire experiment. Femur and tibiotarsus calcium significantly declined between 14 to 28 days and then increased between 28 to 42 days $(P<0.01)$. At 42 and 56 days, there was no significant difference in calcium content. Femur 


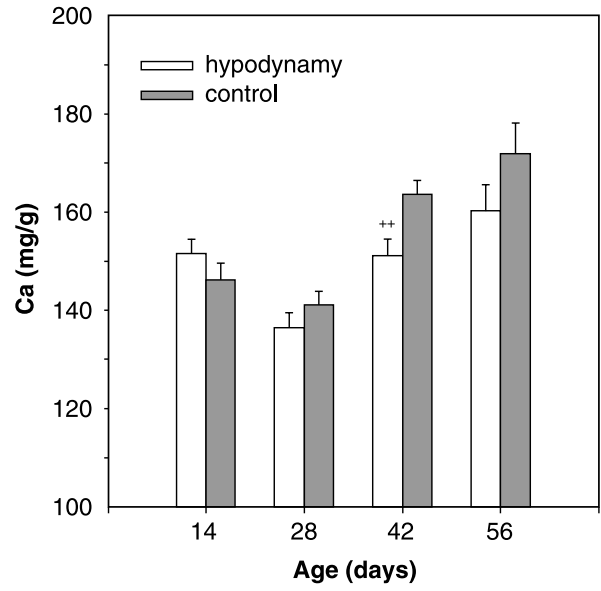

Fig. 1. Calcium content in the femur ( $\mathrm{mg} / \mathrm{g}$ dry bone) $(* * P<0.01)$

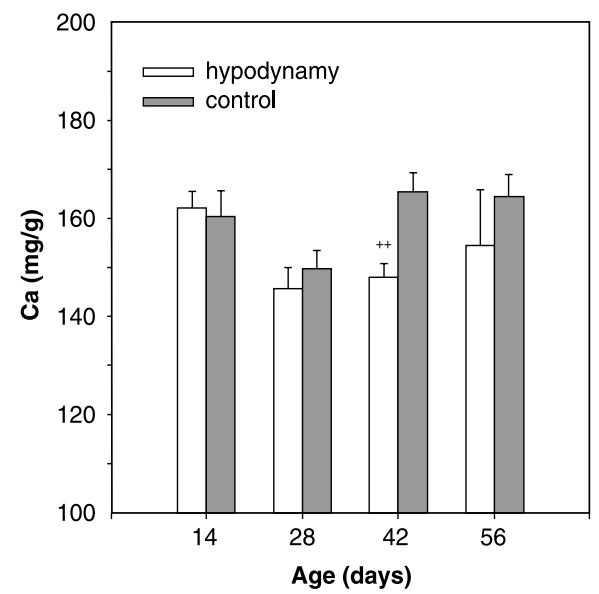

Fig. 2. Calcium content in the tiobiotarsus $(\mathrm{mg} / \mathrm{g}$ dry bone) $\quad(* * P<0.01)$

and tibiotarsus calcium content of hypodynamy quail was lower than control throughout the experiment, except 14 days; a significant difference was only observed at 42 days $(P<0.01)$. The maximum femur and tibiotarsus calcium content in the hypodynamy group was about $160 \mathrm{mg} \cdot \mathrm{g}^{-1}$ at 56 days and $162 \mathrm{mg} \cdot \mathrm{g}^{-1}$ at 14 days, respectively.

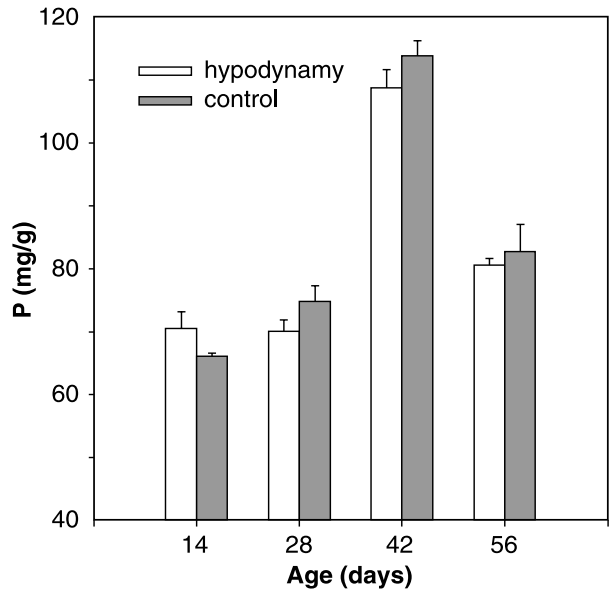

Fig. 3. Phosphorus content in the femur (mg/g dry bone)

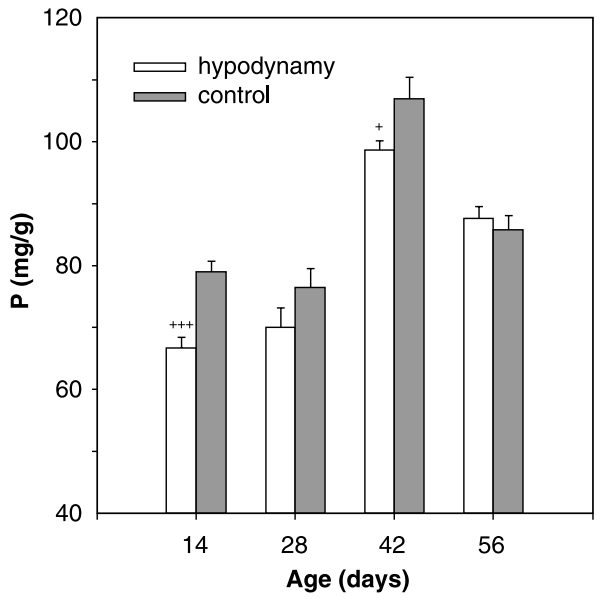

Fig. 4. Phosphorus content in the tibiotarsus (mg/g dry bone) $\quad(* * * P<0.001, * P<0.05)$

The mean femur phosphorus content of hypodynamy group was similar at 14 and 28 days (Fig. 3), but increased significantly at 42 days and had declined again significantly by the end of the experiment $(P<0.001)$. Phosphorus content of the femur in control birds increased from 14 to 42 days and then decreased at 56 days $(P<0.001)$. Similarly, tibiotarsus phosphorus content in the experimental and control group increased to 42 days and then decreased at the end of experiment (Fig. 4). Except for the tibiotarsus phosphorus content at 14 days $(P<0.001)$ and 42 days $(\mathrm{P}<0.05)$, the differences between hypodynamy and control group were not significant. 
The femur magnesium content of test and control quail increased from 14 to 42 days $(P<0.01)$ and decreased significantly at 56 days $(P<0.001)$. Similarly, tibiotarsus magnesium content varied in both groups (Fig. 5 and 6). However, the femur and tibiotarsus magnesium content of test group was non-significantly lower (with the exception in tibiotarsus at 42 days; $P<0.01)$ than the control group throughout the experiment, except 14 days $(P<0.001$ and $P<0.01$, respectively).

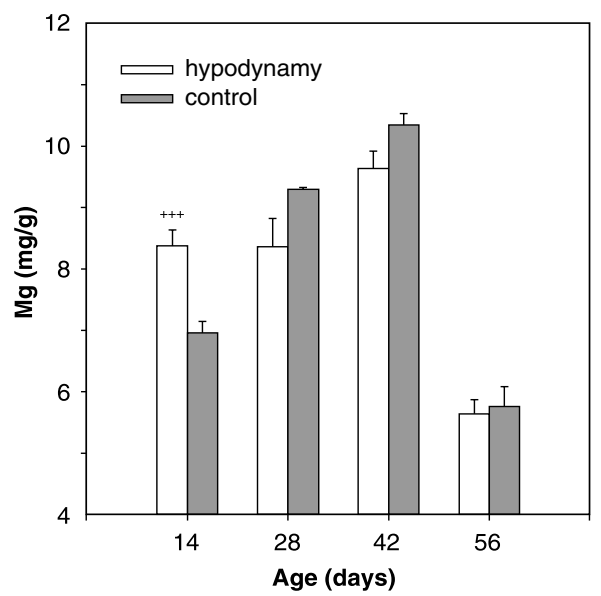

Fig. 5. Magnesium content in the femur ( $\mathrm{mg} / \mathrm{g}$ dry bone) $(* * * P<0.001)$

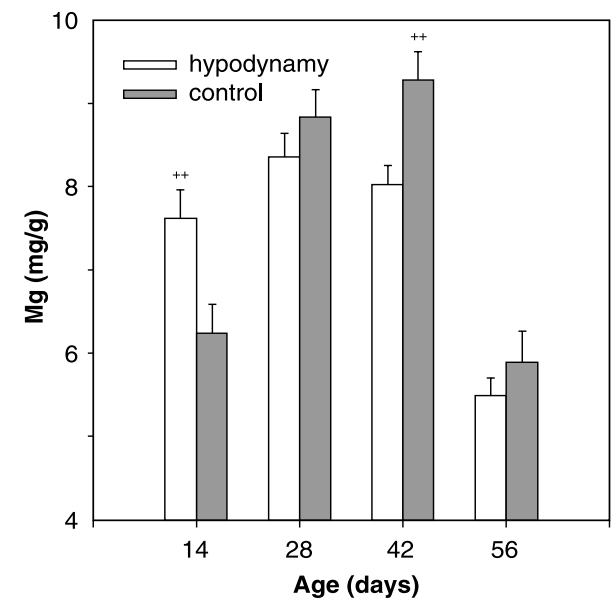

Fig. 2. Magnesium content in the tibiotarsus (mg/g dry bone) $\quad(* * P<0.01)$

\section{Discussion}

Growth is the most studied factor to estimate postnatal development of an individual (Ricklefs 1979; Blom and Lilja 2004). There are many studies that characterise the growth and development in Japanese quail under standard earth conditions (Lilja and Marks 1991; Aggrey 2003; Hyánková et al. 2001). Several studies investigated the rate of long bone development (Starck 1996), however, only a few studies examined the effects of altered gravity (microgravity) on quail postnatal development (B od'a et al. 1992; Sabo et al. 2001).

The purpose of the present study was to evaluate the effect of simulated microgravity (hypodynamy) on the morphology and composition of femur and tibiotarsus of developing Japanese quail females from 3 to 56 days of age. The results demonstrated that hypodynamy had a significant negative effect on most of the morphological characteristics of long bones of the leg for the duration of the experiment. Significant differences were also observed between test and control quail for bone index and breaking strength. Similarly, calcium, phosphorus and magnesium contents of femur and tibiotarsus varied significantly in several intervals of measurement.

This variation was not entirely unexpected, since hypodynamy and microgravity are known to be stressful factors (Juráni et al. 1991). Our previous experiments demonstrate the mean body weight, food consumption and conversion and size of the right leg of female quail chicks, when exposed to simulated weightlessness conditions from hatching to maturity, were significantly reduced as compared with the age-matched controls at 56 days (Škrobánek et al. 2003). Similarly, it was reported that periosteal bone formation and tubular bone growth gradually decreased during the 33-day hypodynamy in legs of adult 
Japanese quail (Guryeva et al. 1998). The hypodynamy treatment also evoked different changes in the calcium and phosphorus content in Japanese quail males and females. The calcium content in the marrow of femur was only slightly changed in hens, while in cockerels it was significantly decreased in the upper part and marrow of the tibiotarsus. Furthermore, changes in the phosphorus content were observed in the male tibiotarsus (Antalík ová et al. 2001). In another study, the 84-days hypodynamy decreased calcium, copper, manganese, zinc, iron and increased phosphorus, magnesium, potassium and natrium content in the femur and tibiotarsus of quail (Sviatko et al. 1998). On the contrary, the distribution of phosphorus in the skeleton of Japanese quail exposed to hypodynamy did not change in the experiments by Jankela et al. (1998). On the basis of these observations it appears that the absence of moving activities in the adult Japanese quail exposed to hypodynamy will be influenced especially the mineral metabolism in the long leg bones than that in the skeleton.

In summary, this report is the first study to examine the effects of simulated microgravity on the leg bone development in Japanese quail from day 3 after hatching to 56 days. The present results indicate that simulated microgravity has a significant impact on the growth and mineral deposition of leg long bones of quail chicks. Hence, this data may be useful for understanding quail ontogeny during exposure to altered gravitation during space flight. However, for appropriate validation of these results, it is necessary to conduct a similar experiment in the weightlessness environment of space.

\section{Vplyv simulovanej mikrogravitácie na vývoj kostí nohy u kurčiat prepelice japonskej}

V práci bol skúmaný vplyv simulovanej mikrogravitácie (hypodynamie) na morfologickú charakteristiku a ukladanie minerálnych látok v dlhých kostiach nohy prepelice japonskej od 3 do 56 dní veku. Za týmto účelom bola vo veku 14, 28, 42 a 56 dní zistovaná hmotnost̉ (g), dížka (mm), šírka (mm), index kosti (hmotnost popola/dížka kosti; $\left.\mathrm{mg} \cdot \mathrm{mm}^{-1}\right)$ a pevnost’ (N) femuru a tibiotarsu, ako aj obsah vápnika, fosforu a horčíka (mg.g-1 suchej kosti).

Hodnoty všetkých sledovaných ukazovatelov sa zvyšovali s vekom zvierat, pričom vplyv hypodynamie bol významný. Priemerná hmotnost tibiotarsu prepelíc pokusnej skupiny bola vo veku prepelíc 56 dní v porovnaní s kontrolou nižšia o $0,154 \mathrm{~g}(P<0,001)$, hoci priemerná hmotnost femuru bola takmer rovnaká. Obdobne, na konci experimentu bola signifikantne znížená priemerná dĺžka tibiotarsu o $3,16 \mathrm{~mm}(P<0,01)$ a jeho priemerná šírka o $0,44 \mathrm{~mm}$ $(P<0,001)$. Redukované boli tiež hodnoty indexu kosti a pevnosti obidvoch kostí pravej nohy zvierat chovaných v hypodynamii $(P<0,001)$. Hypodynamia taktiež signifikantne $(P<0,01)$ znižovala obsah vápnika vo femure a tibiotarse $\mathrm{v} 42$ dňoch; $\mathrm{v}$ tibiotarse bol obsah fosforu signifikantne znížený v 14 a 42 dňoch $(P<0,001 ; P<0,05)$ a obsah horčíka v 42 dňoch veku zvierat $(P<0,01)$. Naopak, obsah horčíka v obidvoch dlhých kostiach pokusných zvierat významne narástol v 14 dňoch veku $(P<0,01)$. Ostatné rozdiely v obsahu minerálnych látok vo femure a tibiotarse neboli štatisticky významné.

$\mathrm{Na}$ základe dosiahnutých výsledkov možno konštatovat', že hoci hypodynamia redukovala rast dlhých kostí pokusných zvierat, dlhé kosti pravej nohy kurčiat prepelice japonskej samičieho pohlavia boli schopné vyvíjat sa aj v podmienkach simulovanej mikrogravitácie.

\section{Acknowledgements}

This work was supported by the Grant Agency for Science of Slovak Republic, VEGA grant No. 2/3046/23.

\section{References}

AGGREY SE 2003: Dynamics of relative growth rate in Japanese quail lines divergently selected for growth and their control. Growth Dev Aging 67: 47-54 
ANTALÍKOVÁ J, BARANOVSKÁ M, MRAVCOVÁ I, SABO V, ŠKROBÁNEK P 2001: Different influence of hypodynamy on calcium and phosphorus levels in bones of male and female Japanese quails. Physiol Res 50: $197-204$

BLOM J, LILJA C 2004: A comparative study of growth, skeletal development and eggshell composition in some species of birds. J Zool Lond 262: 361-369

BOD́A K, SABO V, JURÁNI M, GURYEVA TS, KOČIŠOVÁ J, KOŠŤÁL L, LAUKOVÁ A, DADASHEVA OA 1992: Embryonic development and behaviour of Japanese quail exposed to microgravity. Acta Vet Brno 61: 99-107

DADASHEVA OA, GURYEVA TS, SABO V, BOĎA K, KOČIŠOVÁ J 2001: Research into morphology of Japanese quails hatched under conditions of microgravity. Folia Vet. 45 (Suppl. 1): S12-S16

DANIEL DB, HALLORAN PB, MOREY-HOLTON M 1997: Spaceflight and the skeleton: Lessons from the earth-bound. Grav and Space Biol Bull 10: 119-135

GURYEVA TS, DADASHEVA OA, MELESHKO GI, SHEPELEV YeYa, BOĎA K, SABO V 1993: The quail embryonic development under the conditions of weightlessness. Acta Vet Brno 62 (Suppl. 6): S25-S30

GURYEVA TS, MEDNIKOVA EI, DADASHEVA OA, POVALKO NB 1998: The musculoskeletal apparatus of Japanese quail during hypodynamy. Folia Vet 42 (Suppl.): S37-S39

HYÁNKOVÁ L, KNÍZZETOVÁ H, DĚDKOVÁ L, HORT J 2001: Divergent selection for shape of growth curve in Japanese quail. 1. Responses in growth parameters and food conversion. Br Poult Sci 42: 583-589

JANKELA J, BARANOVSKÁ M, MRAVCOVÁ I, ANTALÍKOVÁ J 1998: The influence of the hypodynamy on the calcium and phosphorus contents in Japanese quail's bones. Folia Vet. 42: (Suppl.): 49-52

JURÁNI M, BOD̃A K, VÝBOH P, ZEMAN M, LAMOŠOVÁ D, SOMOGYIOVÁ E, KOŠŤÁL L, BAUMGARTNER J 1991: An endocrine response to short-term hypodynamy in Japanese quail selected for resistance to hypodynamy. Physiologist 34 (Suppl.): S129-S131

JURÁNI M, VÝBOH P, LAMOŠOVÁ D, BAROŠKOVÁŽ, SOMOGYIOVÁ E, BOĎA,K, GAŽO M 1983: The effect of a 90-day hypodynamy on the neurohumoral system, egg laying and metabolism of proteins in Japanese quail. Physiologist 26 (Suppl. 6): 145-148

LILJA C, MARKS HL 1991: Change in organ growth pattern associated with long-term selection for high growth rate in quail. Growth Dev Aging 55: 219-224

MARCINKA K, GAŽO M 1964: The strength of the egg shells of hens kept in cages. Part II. A contribution towards the determination of the strength of egg shells (In Slovak). In: Vedecké práce Výskumného ústavu pre chov hydiny $2: 237-247$

RICKLEFS R 1979: Patterns of growth in birds. In: A comparative study of development in the starling, common tern and Japanese quail. The Auk 96, pp.10-30

SABO V, BOĎA K, GURYEVA TS, DADASHEVA OA, BELLA I 2001: The study of postembryonic development of Japanese quail chicks under microgravity and load on the orbital station MIR. Folia Vet $\mathbf{4 5}$ (Suppl. 1): S9-S11

SEEDOR G, QUARTUCCIO HA, THOMPSON DD 1991: The bisphosphonate alendronate (MK-217) inhibits bone loss due to ovariectomy in rats. J Bone and Mineral Res 6: 339-346

STARCK JM 1996: Comparative morphological and cytokinetics of skeletal growth in hatchlings of altricial and precocial birds. Zool Anz 235: 53-75

SVIATKO P, BODA K, SABO V 1998: The effect of hypodynamy on the content of mineral substances in the femur and tibiotarsus of Japanese quails. Folia Vet 42: (Suppl.): 45-48

ŠKROBÁNEK P, HRANČOVÁ M 2003: Adaptability of Japanese quail chicks to conditions of simulated weightlessness. Acta Vet Brno 72: 347-351

ŠKROBÁNEK P, SABO V, BOĎA K, BARANOVSKÁ M, MRAVCOVÁ I 2001: The capacity of Japanese quail hatchlings to adapt to hypodynamy. Folia Vet 45 (Suppl. 1): S69-S70 
